\title{
The Aplication of Learning Models of Project Based Learning to Improve Students' Learning Outcomes in Post-Legal Materials
}

\author{
Faradhillah \& Syarifah Rita Zahara* \\ Department of Physics Education, Universitas Malikussaleh, Aceh Utara, Indonesia \\ faradhillah@unimal.ac.id; syarifah.rita@unimal.ac.id \\ *Corresponding Author: syarifah.rita@unimal.ac.id | Phone Number:+6285260932829
}

Received: 11 March 2021

Revised: 26 April 2021

Accepted: 10 May 2021

\begin{abstract}
This study is motivated by the low learning outcomes of students of class VIII 3 SMP Negeri 2 Meurah Mulia which is known from the observations. The research objective was to determine the improvement of learning outcomes in the Pascal Law material for class VIII 3 students of SMP Negeri 2 Meurah Mulia by using project based learning (pjbl) of learning model. This research is a type of classroom action research with a model developed by Kemmis and Mc. Taggart. The study subjects were students of class VIII 3, with a total of 16 students. The techniques used in data collection are tests, observation, interviews and documentation. This study consisted of 2 (two) cycles where there were two meetings in each cycle. The data analysis technique used a qualitative descriptive analysis. The study success criteria set for student learning outcomes is 75 for a scale of 1-100 grading. The results showed that the application of the project based learning (pjbl) of learning model could improve the learning outcomes of class VIII 3 students of SMP Negeri 2 Meurah Mulia. The average learning outcomes in cycle I was 73.16 and in cycle II increased to 82.51 . In conclusion, the application of the project based learning model can improve student learning outcomes in science learning class VIII 3 SMP Negeri 2 Meurah Mulia.
\end{abstract}

Keywords: learning models; project based learning; (PjBL); learning outcomes; Pascal's law;

\section{Introduction}

Education is an important part of the national development process that determines the growth of a country. In the implementation of the 2013 curriculum there were changes to the standard process. These changes include: 1). Learning that initially applies the isolation model, where students just ask the teacher and learn from books in the classroom, becomes learning in the context of networking, where students gain knowledge from various sources; from anyone, from anywhere, from the internet, from the school library, from practical outside and inside the classroom. 2). Learning, which initially develops the capacity of each individual, becomes team-based learning, where the teacher develops individual learning capacities through teamwork (Hartono, 2019). In the teaching and learning process the role of the teacher as class manager is a very important factor. Teacher's activity and creativity in delivering subject matter is one of the aspects that determines the success and smoothness of teaching and learning activities. The variation of teaching that teachers can do in addition to the use of teaching media is also in the use of teaching methods. One of the factors that greatly affects the success of students in taking education is the teacher. A teacher is required to be able to improve the quality of learning. The teacher is the spearhead of the implementation of learning in schools (Negara, 2020).

The teaching and learning process is the main thing that needs attention in achieving learning goals (Negara, 2020). The fact is that in the learning process in the class, the teacher has tried to actively involve students in learning through the assignments given to students by the teacher, but in fact the learning model used by the teacher can be said to be less varied and tends to use a direct learning system where the learning process is still dominated by the teacher (teacher centered), the materials or teaching materials taught to students are still not enough to the daily life of students, the teacher only provides opportunities or appoints one or two students to ask questions then continues the explanation in front of the class, more questions come from the teacher and the types of questions the teacher gives to students are generally in the form of memories so that students answer the teacher's questions simultaneously. The only learning resource is teacher, both as provide information and books, almost no media or learning aids other than books, markers and blackboards. In fact, the learning process is often carried out following the order of the handbook or 
textbook page by page including the questions, so that only some students are actively participating in the learning process while most others feel bored following the learning process.

This is reinforced by opinion (Lestari, 2019) that the learning experiences obtained by students during class are not complete and oriented towards achieving competency standards and basic competencies. Students only study subject matter in the low cognitive domain so that there are still many students who tend to be lazy to think independently, even the ways of thinking developed in learning activities have not touched the affective and psychomotor domains of students. The lack of active student involvement in learning of course affects the achievement of student learning outcomes, that is the low student learning outcomes.

Several previous studies, such as research by Lubis et al (2019), Rachmawan et al (2019), and Pur Wanita et al (2019) found that student learning outcomes are highly dependent on the learning model used by the teacher in the classroom. In line with Artiningsih et al (2019) that the cooperative learning model provides many improvements to students' motivation and learning outcomes. The media used by the teacher along with the learning environment also determines satisfactory learning outcomes for students (Sahronih et al, 2020; Ningsih et al, 2019). One of the effective learning models to improve learning outcomes is the ProblemBased Learning Model (Wahyuni et al, 2020; Aprilianu et al, 2020). In addition to this model, other learning models are commensurate with it, namely Project Work-Based (Fiolentin et al, 2021; Wahyuni et al, 2020) that can significantly improve student learning outcomes. Of course, this model is not enough to improve learning outcomes, other models are needed to support learning activities used by teachers in the classroom. Cooperative learning invites students to be active in every activity-centered activity so that students can improve learning outcomes well (Yulianto et al, 2020). Other learning models that also influence learning outcomes also exist from the Discovery Learning and Inquiry models (Lukitasari et al, 2020; Yulianto et al, 2020; Dewi, 2019 \& Widianto et al, 2020). In addition to the learning model, another element is that the media used also makes it easy for students to digest the message, digest the material presented by the teacher so that in the end students will have good learning achievements (Puspitasari et al, 2020; Dewi, 2019; Sabillah \& Sukmawati, 2020).

Based on the results of observations in class VIII 3 SMP Negeri 2 Meurah Mulia (Junior High School), especially in science learning, the legal material of Pascal shows that the science learning activities carried out still make students memorize the contents of the book to get good cognitive values. So that memorizing activities have an impact on the lack of understanding of students, the lack of honed scientific attitudes of students in science subjects, and the lack of students' ability to find out, be scientific and prove the concepts they have learned. This fact has an impact on the low learning outcomes in the teaching and learning process. In general, they do not understand the concepts being studied. This was reinforced based on the results of the students' initial tests which showed unsatisfactory results, namely the average student learning outcomes of the completed science material were $31.25 \%$, namely 5 people and $68.75 \%$ students who had not completed, namely 11 people the total number of students was 16 people. This can be seen from the KKM science lessons in SMP Negeri 2 Meurah Mulia is 75. Meanwhile, in terms of results, the learning process is said to be successful if there is a positive behavior change in all or at least most of the students (75\%). In other words, students are said to have completed learning if students achieve learning outcomes above predetermined criteria

In order to improve student learning outcomes optimally, teachers are required to be more creative in developing learning models that are able to produce products and involve students actively in the learning process. According to (Negara, 2020) learning methods that can be used to increase student activity and learning outcomes in the teaching and learning process are project-based learning. In general, the projectbased learning model has step guidelines: planning, creating or implementing, and processing. Project-based learning models assist students in learning solid knowledge and skills that are built through authentic assignments and work. Learning using a project-based learning model is very effective in improving student learning outcomes, this is in line with the results of research conducted by Surya, Helmasira and Hardini (2018) which states that the application of learning model of Project Based Learning (PjBL) can improve student learning outcomes and creativity of third grstudents at SD NegeriSidorejoLor 01 Salatiga. At the pre cycle cycle percentage of student learning $46 \%$ and then increased in the first cycle as much as $72 \%$ and increased again to $92 \%$ in cycle II. While the creativity of students in the pre cycle of $29 \%$ increased to $51 \%$ in the first cycle of meeting 2 and increased to $90 \%$ in the second cycle of meeting 2. Furthermore, the results of research conducted by Sari, Satrijono, Sihono (2015) stated that learning

Outcomes on speaking skill, after applying cycle II, there are sixteen students (53,33\%) belong to excellent, eight students $(26,67 \%)$ belong to good, six students $(20 \%)$ belong to fair. So, it can be concluded that the use of Project Based Learning method (Project Based Learning) can improve learning outcomes on speaking skill for class V-A SDN Ajung 03. Research conducted by Lindawati, Fatmariyanti and Maftukhin (2013) states that learning using a project-based learning model can increase students' creativity, this is 
evidenced by the results of research Increasing students' psychomotor creativity before applying the project model based learning with a percentage of $56.31 \%$ increased to $63.40 \%$ in the first cycle and $78.63 \%$ in the second cycle. Enhancement affective creativity of students in the pre-cycle with a percentage of 56.05 to $60.78 \%$ in the first cycle and increased again to $78.94 \%$ in cycle II. Increased cognitive creativity with a percentage of $59.53 \%$ before the cycle to $67.78 \%$ in the cycle I and $80.92 \%$ in the second cycle. Meanwhile, the increase in learning outcomes before project based learning was implemented was $47.36 \%$, in the first cycle it increased to $52.53 \%$ and became $78.94 \%$ in the second cycle

Project-based learning models are learning models that provide opportunities for teachers to manage classroom learning by involving project work. Project work contains complex tasks based on very challenging questions and problems, and requires students to design, solve problems, make decisions, carry out investigative activities, and provide opportunities for students to work independently. This is supported by research (Lestari, 2019) which states that the effect of the project-based learning model is one of the ways that students can easily understand the material being studied and can foster enthusiasm and active student involvement in learning is to apply a project-based learning model. Based on the background described above, the researcher needs to conduct a scientific study regarding the application of the project based learning model to improve IPA student learning outcomes in pascal's law.

\section{Literature Review}

\subsection{Project Based Learning Model (PjBL)}

Project Based Learning (PBL) is a learning model that involves students in an project that produces a product. Students are involved in planning, design, implementation and reporting activities (Hartono, 2019). According to (Negara, 2020) Project-based learning models are learning models that provide opportunities for teachers to manage learning in the classroom by involving project work. Project work contains complex tasks based on very challenging questions and problems, and requires students to design, solve problems, make decisions, carry out investigative activities, and provide opportunities for students to work independently.

Purpose of Using Project-Based Learning Model

1. Encourage and familiarize students to find themselves, conduct research/assessment, apply skills in planning, critical thinking, and problem solving in completing an activity/project

2. Encouraging students to apply certain knowledge, skills, and attitudes into various contexts in completing the activities/projects they are working on

3. Provide opportunities for students to learn to apply interpersonal skills and collaborate in a team as people work together in a team in a work environment or real life

Advantages and Disadvantages of PjBL

1. Increase students' motivation to learn and encourage them to do important work

2. Improve students' ability to solve problems

3. Make students more active in solving complex problems

4. Improve students' ability to work together.

5. Encourage students to practice communication skills

6. Improve students' skills in managing resources.

7. Provide students with experience in organizing projects, allocating time, and processing resources such as equipment and materials to complete assignments.

8. Provide learning opportunities for students to develop according to real conditions.

9. Involve students to learn to gather information and apply that knowledge to solve real-world problems.

10. Make learning atmosphere fun.

Project-Based Learning Steps According to Sani (2015), the project-based learning steps include 6 stages or steps, namely: 1) Asking questions, 2) planning, 3) scheduling, 4) monitoring project creation, 5) evaluating and 6) Evaluation. Understanding Project Based Learning Model Project Based Learning, which if translated into Indonesian means project-based learning, is a learning model that has been widely developed in developed countries such as the United States. Project-based learning according to experts as follows:

1. Project-based learning is a learning model that uses projects/activities as a medium (Daryanto, 2014, p. 23).

2. Project-based learning is a learning that is designed for complex problems and is product-oriented. In the project based learning approach, students develop a project either individually or in groups to produce a product, for example a portfolio. (Mahanal, 2009; 2). 
Through this project-based learning, students can explore a material using various ways that are meaningful to themselves. Students are accustomed to working collaboratively, assessment is done by measuring, monitoring and assessing all learning outcomes and learning resources can be very developed. (Samanthis, 2014; 24). The definition above, through this Project based learning model, a student can not only use teaching aids, but also create a product that is very useful in supporting the learning process.

\subsection{Learning Outcomes}

Learning is a phenomenon experienced by everyone and can occur anywhere, for example at home, school, laboratory, playground, and so on. Everyone has their own way of learning, this happens because a person's view of learning will affect his actions related to learning. (Slameto, 2010) learning is a process of effort carried out by a person to obtain a new behavior change as a whole, as a result of his own experience in interaction with the environment. Meanwhile (Rusman, 2013) learning is one of the factors that influence and play an important role in personal formation and individual behavior.

Factors that affect learning outcomes according to Siwono (2013) including children's intelligence, readiness or maturity of students in following learning activities, students' interest in learning, models of presenting learning materials that provided by the teacher, and a pleasant learning atmosphere that makes students be happier in learning. Meanwhile, according to Sabri (2007) the results learning is influenced by factors from within themselves and environmental factors. These factors are taken into consideration in making improvements to the model existing learning.

The results of research conducted by Siswanto (2016) The research revealed four findings. (1) There was a significant effect of perceptions of teachers' mastery of practice teaching methods on the learning outcomes in the teaching of automotive electrical practice; (2) There was a significant effect of instructional media on the learning outcomes in the teaching of automotive electrical practice; (3) There was a significant effect of the students' motivation on the learning outcomes in the teaching of automotive electrical practice; (4) There was a significant effect of perceptions on teachers' mastery of practical teaching methods, perceptions on instructional media, and students' motivation collectively on the learning outcomes in the teaching of automotive electrical practice.

\subsection{Pascal's Law}

Pascal's law was stated by a French philosopher and scientist, Blaise Pascal (1623-1662) stating that: "If an external pressure is applied to a closed system, the pressure at any point in the fluid will increase in proportion to the external pressure exerted." that any increase in pressure at the surface of the fluid must be transmitted in all directions of the fluid. Pascal's law can only be applied to fluids, generally liquids.

\section{Methods}

This type of study is Classroom Action Research (CAR) using a Project Based Learning model which is useful for improving student learning outcomes in the IPA learning process. This research was conducted in 2 cycles, where each cycle consisted of four main stages as follows: (1) planning, (2) action, (3) observing, and (4) reflecting, four stages this activity is called a problem solving cycle. This study was conducted at SMP Negeri 2 Meurah Mulia. This research was conducted from 4 November to 1 December 2020 in 2 cycles and each cycle consisting of 2 meetings. The subjects in this study were students of class VIII 3 SMP Negeri 2 Meurah Mulia for the 2020/2021 academic year, totaling 16 students. The object of this study is the low student learning outcomes in science subjects.

\section{Research Cycle}

The steps in the next cycle are revised planning, action, observation, and reflection. Before entering cycle 1, a preliminary action is taken in the form of problem identification. The spiral cycle of the stages of classroom action research can be seen in the figure 1 . 


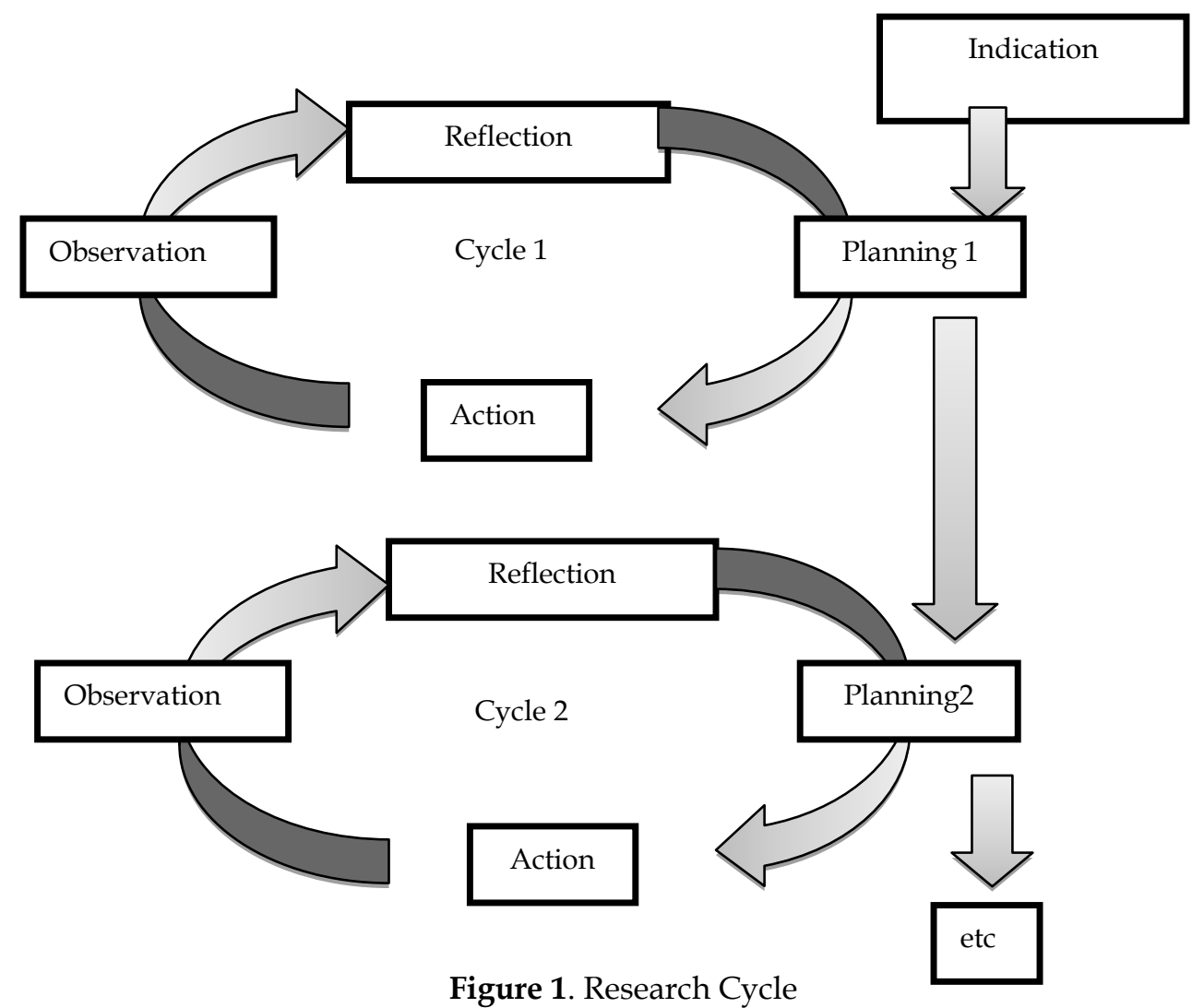

The explanation of the flow above is:

1. Planning : before conducting research, compiling problem formulations, objectives and making action plans, including making research instruments namely observation sheets, student learning activeness questionnaires, and interview guidelines, as well as making learning tools such as salabus and Learning Implementation Plans (LIP).

2. Implementation and observation : includes actions taken as an effort to build students conceptual understanding, namely the application of the project based learning (pjbl) learning model and observing the results or impacts of implementing the learning model project based learning (pjbl).

3. Reflection : the act of reviewing or analyzing, seeing and considering the results or impacts of the actions taken based on the observation sheets filled out by the observer. This reflection stage is the decisive stage, namely to determine what action should be taken next, whether the application of learning should be carried out in the next cycle or it must be stopped because it has reached the predetermined target, which is in accordance with the indicators of learning success.

a) Revised Planning

: a plan designed by the researcher based on the results of the observer's reflection in a particular cycle to be implemented in the next cycle.

In detail, the procedure for this action research can be described in the following description:

Cycle I

b) Planning

1) Preparation of Learning Implementation Plan (LIP) of Cycle I, Cycle I is planned to consist of 2 meetings

2) Preparation of Individual Project Worksheets.

3) Preparation of Group Project Worksheets.

4) Divide study groups.

5) Determine the criteria for successful learning. In this study students are said to be successful if the average student activeness in learning has reached a minimum of 75.00 and for learning outcomes have reached the minimum completeness criteria (MCC) with value 75 .

c) Implementation and Observation

1. Determine the fundamental question.

2. Design project planning.

3. Develop a schedule. 
4. Monitor learners and project progress.

5. Test the results.

6. Evaluating experience.

7. Reflection (Reflection).

\section{Cycle II}

a. Revised Planning

1) Preparation of Learning Implemantation Plans (LIP) Cycle II, Cycle II planned to consist of 2 meetongs

2) Organization of Individual Project Worksheets with three variations.

3) Three variations of Group Project Worksheet

4) Divide into study groups

b. Implementation and Observation

1. Determine the fundamental question

2. Design project planning

3. Develop a schedule

4. Monitor learners and project progress

5. Test the results

6. Evaluating experience

7. Reflection

For data collection in this study carried out by tests, and observation sheets or observation sheets. The two techniques are described as follows:

a. The test is conducted to collect information about student learning outcomes in science learning. The test was carried out at the beginning of the study, at the end of each action, and at the end after a series of actions was given.

b. Interviews were conducted to clarify the test result data.

Data analysis techniques are the process of arranging data sequences, organizing data into patterns or categories of basic descriptions. In this study using qualitative data analysis techniques. The data analysis technique used by the writer is qualitative descriptive analysis, namely presenting the data in the form of a description and discussion based on the research results. The formula for measuring student learning outcomes from a cognitive aspect:

Information:

$$
K B=\frac{T}{T_{t}} X 100 \%
$$

KB : Mastery learning

$\mathrm{T} \quad$ : The total score obtained by students

Tt : Score Total

The formula is to determine student learning activities, affective and psychomotor aspects:

Information:

$$
N P=\frac{R}{S M} X 100 \%
$$

NP : Expected percent value

$\mathrm{R} \quad$ : Raw scores obtained by students

SM : Maximum test score

\section{Calculating Improved Student Learning Outcomes}

To determine the increase in student learning outcomes classically from each cycle, it was done by calculating the difference between Data analysis can be done by looking at the difference in the average student learning outcomes at cycle II and I. If the difference is positive (+), then there is an increase in student learning outcomes in IPA Class VIII 3 SMP Negeri 2 Meurah Mulia and the action hypothesis is proven correct. Conversely, if it is negative (-), then the learning outcomes of students in science class VIII 3 cannot be improved and the action hypothesis is proven to be wrong..

In addition to quantitative data, there is also qualitative data collected through student and teacher activity observation sheets in classroom learning by an observer in the form of an open observation sheet. So that the observer must write a description of his observation results in the column provided in accordance with the question items on the sheet. observation. This qualitative data processing is done by concluding the observer's description of each question item. If the observer writes positive observations of learning, the teacher or student's activities in learning are in accordance with the research expectations. If the opposite 
occurs, the teacher or student's activities in learning are not in accordance with the research expectations. Based on the results of the overall qualitative data analysis, it can be concluded whether all the principles in the Project Based Learning approach have been implemented properly in science learning for Class VIII SMP Negeri 2 Meurah Mulia students.

\section{Research Achievement Indicators}

Research indicators are achieved based on the acquisition of test scores at the end of each cycle that reflect student learning outcomes on the material that has been taught with the hope of an increase in learning outcomes according to the values obtained by each student, namely at least $75 \%$ of the total number of students included in the category of learning outcomes in the final test cycle. It is expected that at least $75 \%$ of students have understood the material presented by implementing Project Based learning.

\section{Results and Discussions}

\subsection{Results}

\section{Normality Test}

Overall, research on the application of the Project Based learning model in improving student learning outcomes in science learning in class VIII 3 SMP Negeri 2 Meurah Mulia shows an increase in student learning outcomes which can be seen from student learning outcomes in Pascal's Law material. Below is a graph that shows an increase in student learning outcomes in cycle II in science learning using the Project Based Learning model.

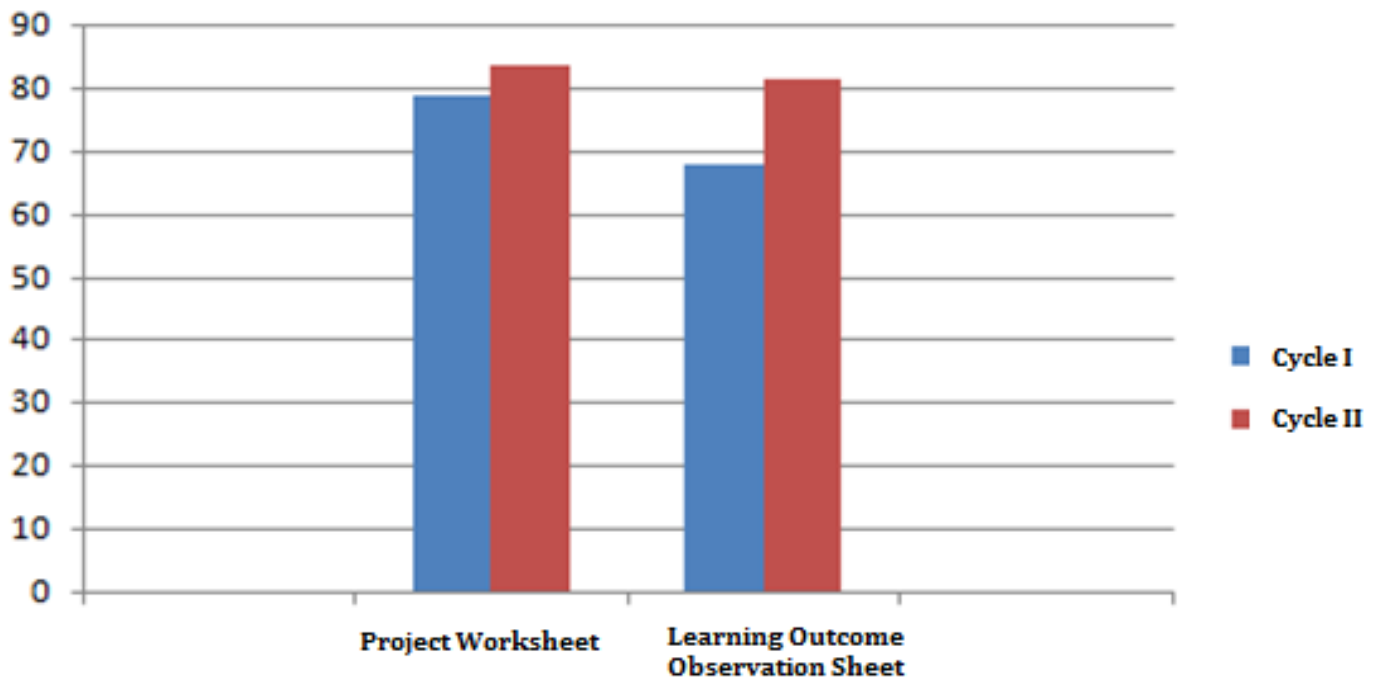

Figure 1. The Success of the Classroom Action Research Cycle

Based on the diagram above, it can be seen that in cycle II there was an increase in student learning outcomes. This can be seen from the results of the evaluation of class VIII 3 students of SMP Negeri 2 Meurah Mulia from cycle I to cycle II.

In cycle 1 the project given is to make a hydraulic jack. The results of the project worksheet corrections in cycle I have met the target for the project worksheet value, which is 70.0 , because the average value of the project worksheets in cycle I is 78.62 and the results of the project worksheet corrections in cycle II have met the target for the sheet value. project work that is equal to 75.0, because the average value of the Project Worksheet in cycle II is 83.62. In cycle II the results of the Project Worksheet corrections have increased from the first cycle which was initially 78.62 increased to 83.62 this is because in cycle 2 students are given the option to choose a project from several projects provided, so that students are more know which project they excel at and which they excel at.

Based on the discussion of student learning outcomes in learning Pascal's Law by applying the project based learning (pjbl) learning model, student learning outcomes have increased so that answering the research problem formulation is by applying the project based learning (pjbl) learning model can improve student learning outcomes VIII 3 in learning Pascal's Law at the same time answers the research objectives, namely an increase in Pascal Law learning outcomes for students of class VIII 3 SMP Negeri 2 Meurah Mulia using a project based learning (pjbl) learning model. 
Based on the discussion of the study results it is known that the student learning outcomes in learning Pascal's Law in learning activities have met the targets for each cycle in learning. This shows that there has been an increase in the quality of the learning activities in the classroom. Nana Sudjana (2009: 62) says that one of the successes of the teaching and learning process is seen from the results achieved by students, namely the number of students who can achieve instructional goals of at least 75 of the instructional numbers that must be achieved. Therefore it can be interpreted that learning is said to be successful and of quality if all or at least the majority $(75.00 \%)$ of students are actively involved, both physically, mentally and socially in the learning process besides showing high learning enthusiasm, great learning enthusiasm. and self-confidence.

Study conducted at SMP Negeri 2 Meurah Mulia succeeded in applying the project based learning (pjbl) learning model to improve student learning outcomes in Class VIII Pascal Law learning activities. The project based learning (pjbl) learning model is more effectively used than the conventional learning model to train students to collaborate better with friends and teachers, train students to actively discuss, train students to dare to express their opinions or knowledge in front of the class, and train students to learn to respect other people who are expressing their opinions.

\section{Conclusion}

Based on the results of the study, data analysis and discussion that has been carried out, it is found that: The application of the Project Based Learning approach can improve student learning outcomes in science lessons related to student learning outcomes in Pascal's Law material. The data on the ability to increase was obtained based on student learning outcomes between cycles where in the first cycle it was $67.70 \%$ and increased in the second cycle $81.41 \%$.

Based on the research conclusion, the following suggestions are made:

1. To the school, especially to schools, it is advisable to involve teachers in seminars, workshops or trainings so that teachers can improve their professionalism in supporting the effectiveness and efficiency of the implementation of teaching and learning in class. By including teachers in seminars and trainings, it will certainly provide experiences for teachers to have the knowledge, ability and willingness to develop learning models.

2. Teachers and other researchers who are interested in conducting classroom action research are expected to develop the use of this project-based learning model in materials and other subjects with heterogeneous grouping of research subjects, heterogeneous in the quality of social skills, student intelligence, learning motivation and interest. student learning. Heterogeneous placement of research subjects allows a more conducive group discussion situation and low-ability students can get help from more capable friends (peer tutors).

\section{Acknowledgement}

The authors would like to thanks to the people who have been instrumental in their assistance and the successful completion of this study.

\section{Author's Contribution}

All authors discussed the result and contributed to from the start to final manuscript.

\section{Conflict of Interest}

The authors declare that they have no competing interests.

\section{References}

Abda, M. I., Muliana, M., \& Fonna, M. (2020). Implementation of Somatic, Auditory, Visual and Intellectual (SAVI) Approaches to Improve Student's Mathematics Communication Skills in SMK Negeri 1 Nisam. International Journal for Educational and Vocational Studies, 2(6).

Aprilianu, D., Rijanto, T., Ismawati, R., \& Wiyanto, T. (2020). The Effect of Problem-Based Learning Model of Food Cutting Competency Toward the Student Learning Outcomes of Class X at SMK YPM 2 Taman. International Journal for Educational and Vocational Studies, 2(3).

Artiningsih, A., Riyanto, Y., \& Harmanto, H. (2019). Influence of Learning Model Type Cooperative Scramble with Picture Media on Motivation and Student's Learning Outcomes of IPS Class 2 SDN 2 Tropodo. International Journal for Educational and Vocational Studies, 1(2), 81-85. 
Daryanto. (2014). Pembelajaran Tematik Terpadu Terintegrasi Kurikulum, Yogyakarta: Gava Media.

Dewi, A. K. (2019). Improving students learning outcomes through mind map in human reproductive system topic in natural science learning. International Journal for Educational and Vocational Studies, 1(7), 702-706.

Fiolentin, E., Kusnan, K., Suparji, S., \& Rijanto, T. (2021). Project Work Based Modules Development on Construction and Building Utilities Subjects to Increase Student Learning Outcomes of Vocational High School. International Journal for Educational and Vocational Studies, 3(2), 103-109.

Hartono, B. (2019). Upaya Peningkatan Hasil Belajar Siswa Konsep Listrik Statis dan Kapasitor Dengan Model Pembelajaran Berbasis Proyek Web Interaktis Pada Siswa Kelas XII MIPA 5 SMA Negeri 2 WonogiriSemester Gasal Tahun 2016-2017.Jarlitbang Pendidikan, 55-62.

Gallagher, Shelag A. and Gallagher, James J. (2013). Using Problem Based Learning to Explore Unseen Academic Potential. IJPBL Interdisciplinary Journal of Problem-Based Learning. 7(1), pp.111-131.

Hasibuan, I. (2015). Hasil Belajar Siswa Pada Materi Bentuk Aljabar Di Kelas VII SMP Negeri 1 Banda Aceh Tahun Pelajaran 2013/2014. Jurnal Peluang , 5- 11.

Junaidi, Ariani2, T., \& Arini, W. (2019). Pengaruh Model Pembelajaran Word SquareTerhadap Hasil Belajar Fisika. Science and Physics EducationJournal. 72-81.

Lestari, N. (2019). Penerapan Model Pembelajaran Berbasis Proyek Untuk Meningkatkan Aktivitas Dan Hasil Belajar Siswa Kelas V SD AR- RAHMAN MISRIADI Desa Stabat Lama Langkat. Jurnal Pendidikan dan Pembelajaran Terpadu (JPPT) , 13-23.

Lindawati, Fatmariyanti and Maftukhin (2013). Penerapan Model Pembelajaran Project Based Learning Untuk Meningkatkan Kreativitas Siswa Man I Kebumen. Radiasi Jurnal Berkala Pendidikan Fisika. 42-45.

Lubis, R. R., Irwanto, I., \& Harahap, M. Y. (2019). Increasing Learning Outcomes and Ability Critical Thinking of Students Through Application Problem Based Learning Strategies. International Journal for Educational and Vocational Studies, 1(6), 524-527.

Lukitasari, F., Nurlaela, L., Ismawati, R., \& Rijanto, T. (2020). Comparison of Learning Outcomes Between Discovery Learning with Inquiry Learning Reviewed of Student Learning Independence At Vocational High School. International Journal for Educational and Vocational Studies, 2(10).

Mahanal. 2009. Model-model Pembelajaran. Yogyakarta: Gava Media.

Mulyono. (2011). Strategi Pembelajaran Menuju Efektivitas Pembelajaran di Abad Global. UIN-Maliki Press .

Mun'im, A., Sudarto, \& Mahfud, M. (2018). Pengaruh Penggunaan Model Pembelajaran Koperatif Berbasis Kontekstual Terhadap Hasil Belajar Peserta Didik Kelas ( Studi Pada Materi Pokok Interaksi Makhluk Hidup Dengan Lingkunagan). IPA Terpadu , 79-85.

Ningsih, W. K., Riyanto, Y., \& Suyanto, T. (2019). The development of pop up 3d general map using discovery learning models to improve creativity and learning outcomes of social studies grade $\mathrm{V}$ elementary school. International Journal for Educational and Vocational Studies, 1(2), 86-91.

Nahdi, D. S., Yonanda, D. A., \& Agustin, N. F. (2018).Upaya Meningkatkan Pemahaman Siswa Melalui Penerapan Metode Demonstrasi Pada Mata Pelajaran IPA. Cakrawala Pendas , 9-16.

Negara, I. M. (2020). Penerapan Model Pembelajaran Berbasis Proyek Dapat Meningkatkan Hasil Belajar Teknik Pengambilan Gambar Siswa Kelas XII MM 1 SMK N 1 MAS UBUD Semester Ganjil. Tahun Pelajaran 2017/2018. 8191.

Nurlaili. (2016). Penerapan Model Pembelajaran Contextual Teaching and Learning (CTL) Dalam Meningkatkan Hasil Belajar Siswa Pada Mata Pelajaran Geografi Kelas XI 1 IS Di SMA Negeri 5 Banda Aceh. JurnalPendidikan Serambi Ilmu, 318-329.

Purwanita, Y., Riyanto, Y., \& Suyanto, T. (2019). The Influence of Multimedia Assisted Inquiry Learning Methods on My Heroes' Theme of Critical Thinking Skills and Learning Outcomes of Class IV Students of Elementary School. International Journal for Educational and Vocational Studies, 1(2), 75-80.

Puspitasari, R., Miarsyah, M., \& Rusdi, R. (2020). Flash Based Interactive Multimedia Development to Increasing Learning Outcomes of Participants in High School in Materials Excretory System. International Journal for Educational and Vocational Studies, 2(4).

Rachmawan, A. I., Muslim, S., \& Suprianto, B. (2019). Effect of Media Trainer on Electromagnetic Control and Industrial Panel on Learning Outcomes. International Journal for Educational and Vocational Studies, 1(7), 719-723.

Sahronih, S., Purwanto, A., \& Sumantri, M. (2020). The effect of use interactive learning media environment-based and learning motivation on science learning outcomes. International Journal for Educational and Vocational Studies (IJEVS), 2(3). 
Sabillah, B. M., \& Sukmawati, S. (2020). The Implementation of Quantum Teaching Learning Model to Improve Learning Outcomes of Class V Students SD Borong Jambu II of Makassar. International Journal for Educational and Vocational Studies, 2(11).

Saputra, D. S., Yuliati, Y., \& Agustina, W. J. (2019). Penerapan Model BrainBased Learning Bernuansa Lingkungan Sekitar Dalam Meningkatkan Pemahaman Siswa Pada Pembelajaran IPA Di Kelas V Sekolah Dasar. Lensa Pendas , 1-9

Sari, Satrijono, Sihono (2015). The Application of Method Project Based Learning for Improving Learning Outcomes on Speaking Skill of Students VA SDN Ajung 03. Jurnal Edukasi, 11-14

Servitri. (2017). Pembelajaran Multimedia IPA Dengan Model Contextual Teaching and Learning Untuk meningkatkan Hasil Belajar Siswa. ejournal .

Setiawan, W. E., \& Rusmana, N. E. (2019). Penerapan Model Pembelajaran Berbasis Proyek Dalam Peningkatan Pemahaman Konsep Dan Perbaikan Miskonsepsi Siswa Kelas V SD Negeri Gunung Sari . Prosiding Seminar Nasional Pendidikan Universitas Subang (SENDINUSA) , 205-213.

Siswono, T. Y. (2005). Upaya Meningkatkan Kemampuan Berpikir Kreatif Siswa Melalui Pengajuan Masalah. Jurnal Pendidikan Matematika dan Sains, (1), 1-9

Siswanto (2016). Factors Affecting The Learning Outcomes In The Teaching And Learning Of Automotive Electrical Practice Of Smk In Yogyakarta City. Jurnal Pendidikan Vokasi, 111-120

Susiloningsih, W. (2016). Model Pembelajaran CTL ( Contextual Teaching and Learning) Dalam Meningkatkan Hasil Belajar mahasiswa PGSD Pada Matakuliah Konsep IPS Dasar. PEDAGOGIA ISSN 2089 -3833 , 57-66.

Surya, Helmasira dan Hardini. (2018). Penerapan Model Pembelajaran Project Based Learning (PJBL) Untuk Meningkatkan Hasil Belajar Dan Kreatifitas Siswa Kelas Iii Sd Negeri Sidorejo Lor 01 Salatiga.Jurnal Pesona Dasar, 41-54.

Sugiyono. (2013). Metode Penelitian Pendidikan. Bandung: Alfabeta.

Samanthis. (2014). Pembelajaran Abad 21. Yogyakarta: Gava Media.

Wahyuni, D., Samani, M., Wiyanto, T., \& Rijanto, T. (2020). Influences of Problem-Based Learning Models on Class XI Students Learning Outcomes in Subject of Light Vehicle Engine Maintenance at KAL-1 Vocational School Surabaya. International Journal for Educational and Vocational Studies, 2(5).

Widiantoro, O., Kusnan, K., Suparji, S., \& Rijanto, T. (2020). Differences in Learning Outcomes Using Direct Learning Models Viewed from Spatial Ability: Study At Basic Survey Working Lesson in the Engineering Surveying. International Journal for Educational and Vocational Studies, 2(4).

Wulandari, B., \& Surjono, H. D. (2013). Pengaruh Problem-Based Learning Terhadap Hasil Belajar Ditinjau Dari Motivasi Belajar PLC Di SMK. Pendidikan Vokasi , 179-191.

Yulianto, I., Warsono, W., Nasution, N., \& AP, D. B. R. (2020). The Effect of Learning Model STAD (Student Team Achievement Division) Assisted by Media Quizizz on Motivation and Learning Outcomes in Class XI Indonesian History Subjects at SMA Trimurti Surabaya. International Journal for Educational and Vocational Studies, 2(11). 